\title{
Comparative study of antidiabetic effect of Abroma augusta and Syzygium cumini on alloxan induced diabetic rat
}

\author{
Laizuman Nahar ${ }^{1}$, Farhana Alam Ripa ${ }^{1}$, Abu Hasanat Md. Zulfiker ${ }^{1}$, \\ Md. Rokonuzzaman ${ }^{2}$, Mahmuda Haque ${ }^{3}$, Dr. Kazi Mohammed Shahariar Islam ${ }^{1}$ \\ ${ }^{1}$ Lecturer, Department of Pharmacy, Southeast University Banani, Dhaka-1213 \\ ${ }^{2}$ School of Pharmacy, Khulna University, Khulna \\ ${ }^{3}$ Assistant Professor, Department of Pharmacy, Southeast University Banani, Dhaka-1213
}

\begin{abstract}
Herbal formulations are getting more importance in the treatment of diabetes, cancer and hepatic disorder because of the hazardous adverse effects of the current therapy. Especially diabetes can be controlled by Allopathic medicine as well as Herbal medicine. This study would be helpful for the industry to produce herbal formulation with less side effects and cost effective treatment for diabetes. Moreover in vivo models were utilized to test the antidiabetic property and it will be useful for fix the optimized dose in herbal formulation. The findings of the bioactive molecule from the herbals would be effective drug target against the diabetes. A comparison was made between the antidiabetic activities of methanolic extracts of leaves of Abroma augusta and seeds of Syzygium cumini in alloxan induced diabetic rats. Serum glucose level, weight variation and other histopathological studies were conducted at the dose $300 \mathrm{mg} / \mathrm{kg}$ body weight for 7 days. There was a significant decrease in serum glucose level $(p<0.001)$, increase in body weight and changes in normal cells was observed with treatment of the above mentioned extracts which altered in diabetic rats as compared to the standard.
\end{abstract}

Key words: Abroma augusta, Syzygium cumini, antidiabetic

\section{INTRODUCTION}

Diabetes mellitus is a metabolic disorder characterized by hyperglycaemic, glucoseurea and negative nitrogen balance and it is mainly due to lack of insulin secretion in beta cells of pancreas and desensitization of insulin receptors for insulin. It is the most prevalent disease in the world affecting $25 \%$ of population and afflicts 150 million people and is set to rise to 300 million by 2025 (Vats et al., 2005). It causes number of complications like retinopathy, neuropathy, and peripheral vascular insufficiencies (Chehade et al., 2005). Diabetes is still not completely curable by the present anti diabetic agents. Insulin therapy is the only satisfactory approach in diabetic mellitus, even though it has several drawbacks like insulin resistance (Piedrola et al., 2001), anorexia, brain atrophy and fatty liver in chronic treatment (Weidmann et al., 1993). Herbal drugs are gaining popularity in the treatment of diabetic mellitus (Pari et al., 1999). The major advantages of herbal medicine seem to be their efficacy, low incidence of side effects, and low cost.

Abroma augusta, locally known as Ulatkambal, is a flowering plant growing to a height of about 3 to 4 meters, the leaves are narrow and entire and the flowers are $5 \mathrm{~cm}$, belonging to the family malvaceae found in Asia and Australlia. Syzygium cumini, locally known as Jam, is a tree grows up to 18 meters tall and bears thorns and fragrant flowers, stem and branches are light brown to green, leaves are alternate, pale green, belonging to the family Martaceae found in Africa, Madagascar through southern Asia east through the Pacific.

Abroma augusta have hypoglycemic effect on alloxan induced diabetic rats (Hussain MEMA et al., 2001). Syzygium cumini have alpha glycosidase inhibitory activity (Shindi J et al., 2008).In folk medicine Syzygium cumini were used in treating diabetes diarrhoea and ringworm(Abdul Ghani; 2003) And the leaves of Syzygium cumini are antibacterial and are used for strengthening the teeth and gums. Here we report hypoglycemic activity of the methanolic extract from leaves and seeds of Abroma augusta and Syzygium cumini with a view to provide scientific evidence of modern lines in alloxan induced diabetic rat (AIDR).

\section{MATERIALS AND METHODS}


Collection and Identification of Plant: The fresh leaves of the plant Abroma augusta (Ulatkambal) and seeds of Syzygium cumini (Jam), were collected during the month of February 2009 from the area of Homna Thana, Comilla, Bangladesh. The fresh leaves of those plants were taxonomically identified from The National Herbarium of Bangladesh. Identification number is Abroma augusta (34350) and Syzygium cumini (34351).

Extraction of Plant Material: About $100 \mathrm{gm}$ powder material of each plant (leaves of Abroma augusta and seeds of Syzygium cumini) was taken in each separate glass jar and soaked in methanol. The container with its content was sealed by cotton plug and aluminium foil and keep for a period of 7 days accompanying occasional shaking and stirring. The extracts were then filtered through filter paper (Double Rings filter paper 102, $11.0 \mathrm{~cm}$ ). The filtrates were concentrated at $50^{\circ} \mathrm{C}$ under reduce pressure using vacuum pump rotary evaporator (STUART RF3022C, UK) to afford a greenish mass of leaves and seeds extracts.

Experimental animal: Experiment was conducted on adult albino rats of either sex with the weights of 110$165 \mathrm{gm}$ procured from International Centre for Diarrhoeal Disease Research Bangladesh (ICDDRB). All rats were fed normal laboratory chow food containing $16 \%$ protein, $66 \%$ carbohydrate, $8 \%$ fats and water. All rats were housed at a (12:12) hr light and dark cycle at $25^{\circ} \mathrm{C}$ and relative humidity (6070)\%.

Ethical Approval: The guidelines followed for animal experiment were approved by the institutional animal ethical committee (Zimmermann M, 1983).

Experimental Design: Animals were divided into six groups and for each group six animals were taken.

Group I (Normal control) rats served as positive control received physiological saline $(0.9 \% \mathrm{NaCl}$; $5 \mathrm{ml} / \mathrm{kg}$.b.w.p.o).

Group II (Diabetic Control) Diabetes was induced by intraperitoneal injection of Alloxan.

Group III rats were administered Metformin Hydrochloride (100 mg/kg/day) and Group IV rats were treated with Glibenclamide $(0.05 \mathrm{mg} / \mathrm{kg} /$ day $)$ at an interval of $24 \mathrm{hr}$ for seven consecutive days and served as standard.

Group $V$ rats were received intraperitoneal injection of Abroma augusta (300 $\mathrm{mg} / \mathrm{kg} /$ day) while group $\mathrm{VI}$ rats were received Syzygium cumini (300mg/kg/day) at an interval of $24 \mathrm{hr}$ for seven consecutive days. Blood glucose was measured on 1st, 3rd and 7th day. At the 8th day all the animals were sacrificed and evaluated for the biochemical and histopathological studies.

Preparation of Alloxan solution: At first body weight of rats were measured. Then required amount of Alloxan was measured according to the body weight by following the dose of $110 \mathrm{mg}$ of Alloxan per $1000 \mathrm{gm}$ of body weight. Then calculated amount of Alloxan was dissolved in $0.1 \mathrm{ml}$ of sterile normal saline water.

Induction of alloxan: The rats were injected Alloxan monohydrate, dissolved in sterile normal saline water at a dose of $110 \mathrm{mg} / \mathrm{kg}$ body weights intraperitoneally once a day. Alloxan is capable of producing fatal hypoglycemia as a result of massive pancreatic insulin release; therefore the rats were treated with glucose solution orally. After few days rats with moderate diabetes having glycosuria and hyperglycemia that is blood glucose level exceed normal level.

Preparation of dosage of active drug and plant extract: Metformin hydrochloride (a biguanide): Metformin hydrochloride was in microcrystalline form and freely soluble in water. The dosage was prepared in solution form using sterilized water in such a concentration that each $0.1 \mathrm{ml}$ contained metformin hydrochloride according to the dose of 100 $\mathrm{mg} / \mathrm{kg} /$ day, since metformin is effective in such dose in case of humans.

Glibenclamide (a sulfonylurea):Glibenclamide was in powder form and soluble in dimethyl sulfoxide (DMSO) and dosage was prepared in solution form using $90 \%$ DMSO in such a concentration that each $0.1 \mathrm{ml}$ contained glibenclamide according to the dose $0.05 \mathrm{mg} / \mathrm{kg} / \mathrm{day}$, singe glibenclamide is effective in such concentration in case of humans.

Abroma augusta or Ulatkamble: The crude extract obtained from leaves was dissolved in 99\% DMSO to prepare the solution where each $0.1 \mathrm{ml}$ contained Abroma augusta according to the dose of 300 $\mathrm{mg} / \mathrm{kg} / \mathrm{day}$.

Syzygium cumini or Jam: The dried extract obtained from leaves was dissolved in DMSO to prepare the solution where each $0.1 \mathrm{ml}$ contained Syzygium cumini according to the dose of $300 \mathrm{mg} / \mathrm{kg} / \mathrm{day}$.

$0.1 \mathrm{ml}$ of each solution was administered everyday during treatment to achieve required dose of respective agents. 
Biochemical Assay: Fasting blood glucose level was evaluated in normal and diabetic rats from the tail vein by strip method (Bioland Glucometer, Germany). At first it is done just before extract administration of first day then it is continued for 7 days just one hour after the administration of plant extract.

Measurement of weight variations: The variations in weight were measured for both diabetic and normal rats.

Histopathological Studies: After sacrificing the rat's heart, liver and lungs, tissues were collected and histological examination was carried out by Raghuramulu method. Tissue fixation was carried out immediately after removal from the body with $10 \%$ neutral buffered formaldehyde solution ( $\mathrm{pH} 7.0)$. All tissues were cleaned and embedded by using xylene and paraffin (melting point $58-60^{\circ} \mathrm{C}$ ). Tissues were stained by double staining. To differentiate the nucleus and cytoplasm, the basic dye haematoxylin and the acid dye eosin were used (Kehar et al., 1967). Electron micrographs were performed using transmission electron microscope and photographed by photomicrography.

\section{RESULT}

Effect on blood glucose and body weight: Alloxan (110 mg/kg body weight) administration resulted in significant elevation of glucose level and reduction in body weight. Administration of Abroma augusta and Syzygium cumini at a dose of $300 \mathrm{mg} / \mathrm{kg}$ body weight administered for seven days were able to correct this aberration significantly $(p<0.001)$. The results of all the formulations tested are presented in Table 1.

Before treatment schedule, fasting blood glucose level in all animals was within normal range. After treatment with Alloxan, the fasting blood glucose level was significantly changed and it was significantly $(P<0.001)$ reduced by 7 days treatment with methanolic extract of Syzygium cumini and Abroma augusta that is comparable to the standard Glibenclamide and Metformin $\mathrm{HCl}$. On the progression of treatment with methanolic extract of Syzygium cumini (300 mg/kg/day) and Abroma augusta (300mg/kg/day) fasting blood glucose level reduced at $9.28 \pm 0.46 \mathrm{mmol} / \mathrm{L}$ and $9.90 \pm 0.37$ $\mathrm{mmol} / \mathrm{L}$ respectively on $3^{\text {rd }}$ day (Table 1 .). At the end of experiment ( $7^{\text {th }}$ day) fasting blood glucose (FBG) level was $7.55 \pm 0.20$ and $7.95 \pm 0.11 \mathrm{mmol} / \mathrm{L}$ in the doses of Syzygium cumini (300 mg/kg/day), and Abroma augusta (300mg/kg/day) respectively.

The findings of our study agrees to reports of study (Giovanni et al., 2006) that showed treatment with extracts of Abroma augusta and Syzygium cumini improved the weight compared to untreated diabetic rat significantly $(p<0.001)$ ( Table 2$)$.

Statistical Analysis: Data are expressed as mean \pm SEM and were analyzed by the analysis of variance (ANOVA)followed by Post hoc Dunnet's multiple comparisons test, using SPSS 16.00 (USA). For all the tests, results with $P$ values $<0.05,0.001$ were taken to imply statistical significance.

Table-1: Effect of Abroma augusta and Syzygium cumini on Fasting blood glucose (FBG) level in normal and Alloxan induced diabetic rat (AIDR).

\begin{tabular}{|c|c|c|c|}
\hline \multirow{2}{*}{ Name of the Group } & \multicolumn{3}{|c|}{ Fasting Blood Glucose (FBG) Level $\mathrm{mmol} / \mathrm{L}$} \\
\hline & $1^{\text {st }}$ day & $3^{\text {rd }}$ day & $7^{\text {th }}$ day \\
\hline $\begin{array}{c}\text { Group-I } \\
\text { (Non Diabetic) }\end{array}$ & $4.83 \pm 0.14$ & $4.92 \pm 0.12$ & $5.52 \pm 0.18$ \\
\hline $\begin{array}{c}\text { Group-II } \\
\text { (Diabetic Control) }\end{array}$ & $19.52 \pm 0.53$ & $17.32 \pm 0.82$ & $16.03 \pm 0.74$ \\
\hline $\begin{array}{c}\text { Group-III } \\
\text { Metformin } \mathrm{HCl} \\
(100 \mathrm{mg} / \mathrm{kg} / \mathrm{day})\end{array}$ & $8.53 \pm 0.27^{\star \star}$ & $6.60 \pm 0.26^{\star \star}$ & $4.40 \pm 0.26^{\star *}$ \\
\hline $\begin{array}{l}\text { Group-IV } \\
\text { Glibenclamide } \\
(0.5 \mathrm{mg} / \mathrm{kg} / \mathrm{day})\end{array}$ & $8.01 \pm 0.18^{\star \star}$ & $6.05 \pm 0.14^{\star \star}$ & $5.00 \pm 0.18^{\star \star}$ \\
\hline $\begin{array}{c}\text { Group- } V \\
\text { Abroma augusta (300mg/kg/day) }\end{array}$ & $10.15 \pm 0.32^{\star \star}$ & $9.28 \pm 0.46^{\star \star}$ & $7.55 \pm 0.20^{\star \star}$ \\
\hline $\begin{array}{c}\text { Group-VI } \\
\text { Syzygium cumini (300mg/kg/day) }\end{array}$ & $10.80 \pm 0.18^{\star \star}$ & $9.90 \pm 0.37^{\star \star}$ & $7.95 \pm 0.11^{* \star}$ \\
\hline
\end{tabular}

Results are presented as mean \pm SEM, $(n=6),{ }^{*}: p<0.05,{ }^{* *}: p<0.001$ dunnet test as compared to diabetic control (Gr-II). 
Table-2: Effect of Abroma augusta and Syzygium cumini on body weight in normal and Alloxan induced diabetic rat (AIDR).

\begin{tabular}{|c|c|c|c|c|}
\hline \multirow{3}{*}{ Name of the group } & \multicolumn{4}{|c|}{ Weight variation (average) } \\
\hline & \multirow{2}{*}{$\begin{array}{c}\text { Prior to the } \\
\text { treatment(gm) }\end{array}$} & \multicolumn{3}{|c|}{ After treatment (gm) } \\
\hline & & 1st day & 3rd day & 7th day \\
\hline $\begin{array}{c}\text { Group-I } \\
\text { (Non Diabetic) }\end{array}$ & $113 \pm 0$ & $112 \pm 0.707$ & $112 \pm 0.707$ & $114 \pm 0.707$ \\
\hline $\begin{array}{c}\text { Group-II } \\
\text { (Diabetic Control) }\end{array}$ & $90 \pm 0.707$ & $110 \pm 0.707$ & $111 \pm 0.408$ & $110 \pm 0.707$ \\
\hline $\begin{array}{c}\text { Group-III } \\
\text { Metformin HCl } \\
(100 \text { mg/kg/day })\end{array}$ & $105 \pm 0.707^{\star *}$ & $110 \pm 0.707^{\star \star}$ & $115 \pm 0.707^{\star \star}$ & $120 \pm 0.707^{\star *}$ \\
\hline $\begin{array}{c}\text { Group-IV } \\
\text { Glibenclamide } \\
(0.5 \mathrm{mg} / \mathrm{kg} / \mathrm{day})\end{array}$ & $130 \pm 0.707^{* *}$ & $135 \pm 0.707^{\star *}$ & $150 \pm 0.707^{\star \star *}$ & $150 \pm 0.707^{\star *}$ \\
\hline $\begin{array}{c}\text { Group-V } \\
\text { Abroma augusta } \\
\text { (300mg/kg/day) }\end{array}$ & $150 \pm 0.707^{\star *}$ & $155 \pm 0.707^{\star *}$ & $165 \pm 0.408^{\star \star}$ & $145 \pm 0.408^{\star *}$ \\
\hline $\begin{array}{c}\text { Group-VI } \\
\text { Syzygium cumini } \\
\text { (300mg/kg/day) }\end{array}$ & $100 \pm 0.408^{\star \star}$ & $115 \pm 0.707^{\star *}$ & $120 \pm 0.408^{\star \star}$ & $120 \pm 0.408^{\star *}$ \\
\hline
\end{tabular}

Results are presented as mean \pm SEM, $(n=3),{ }^{*}: p<0.05,{ }^{*}: p<0.001$ dunnet test as compared to diabetic control (Gr-II).

Histopathological Findings: In the diabetic group, the cytoplasm of peri-acinar hepatocytes showed either a single large or multiple small round empty vacuoles that distended the cell cytoplasm and displaced the nucleus to the periphery in histological sections of liver stained with haematoxylin and eosin.

A

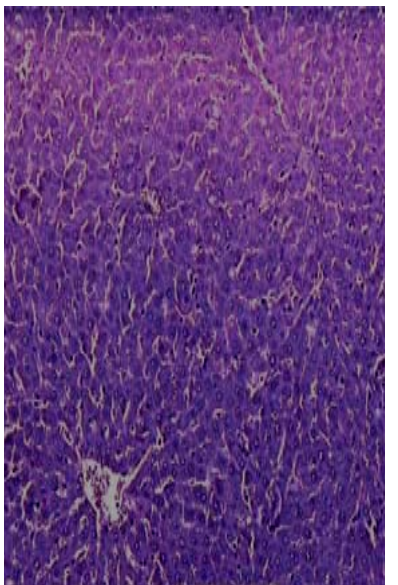

These degenerative changes were also seen, to a lesser extent, in the midzonal regions. Parenchymatous degeneration was observed in the peripheral regions. Dissociation of hepatocytes and sinusoidal dilatation occurred due to these changes. These histopathological changes were restored by treatment with the extract (Fig 1)

C

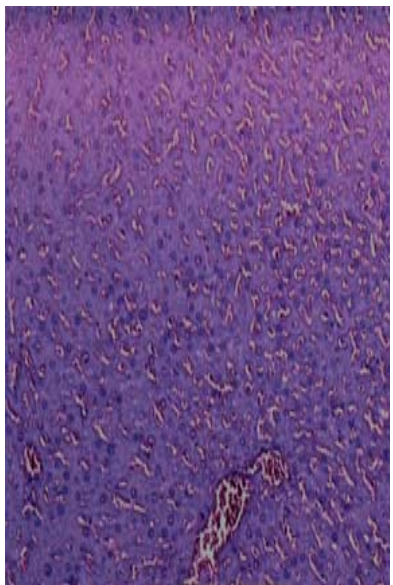

Fig 1. Histological examinations of 7days experimental rat liver. A. The normal histological section shows the well arranged cells and clear central vein. B. Section shows the complete destruction of hepatocytes degeneration of central vein, fatty degeneration and neutrophil distribution $\mathbf{C}$. Histopathological changes are restored near to normal in the group treated by the extract. (All figures are in 10x magnification).

DISCUSSION

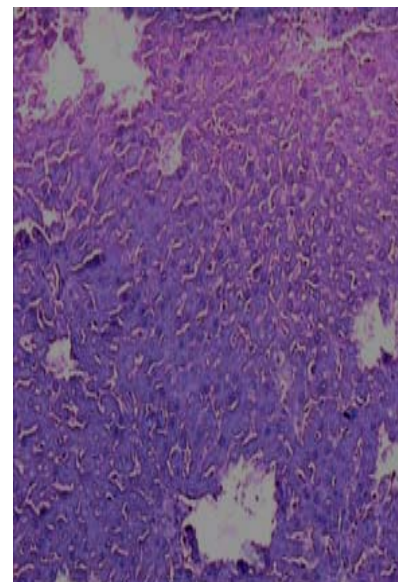

Use of herbal medicine is a common practice in many countries, particularly in Asia ( Chacko et al., 2003) 
and Africa ( Shapiro et al., 2002). Alloxan, a beta cytotoxin, induces diabetes in a wide variety of animal species by damaging the insulin secreting pancreatic beta cell resulting in a decrease in endogenous insulin release, which paves the ways for the decreased utilization of glucose by the tissues (Omamoto, H. et al., 1981) Insulin deficiency leads to various metabolic aberrations the animals namely increase blood glucose (Chude, M.A. et al., 2001), decreased protein content (Ghosh, S. et al., 2001). The present study was conducted to evaluate and to compare the antidiabetic activity of some marketed formulations with the plant extract. The experimental groups were treated with standard (Glibenclamide + Metformin) and test formulations. The experiment was conducted in accordance with parallel design i.e. each group received single formulation, single time. After completion of the study protocol, it was found that with test and standard treatment, the serum level of glucose reduced significantly $(p<0.001)$ as compared to diabetic control. The significant antidiabetic activity of formulations may be due to inhibition of free radical generation and subsequent tissue damage induced by alloxan or potentiation of plasma insulin effect by increase either pancreatic secretion of insulin from existing beta cells or its release from bound form as indicated by significant improvement in glucose level because insulin inhibit gluconeogenesis from protein. In comparative evaluation of Abroma augusta and Syzygium cumini, later was found to be more efficacious as compared to first one.

The antidiabetic activity of the plant extract was also confirmed by the increase in weight of the alloxan induced diabetic rat.

Histopathological studies of liver in diabetic and extract treated groups substantiate the cytoprotective action of the extract.

\section{REFERENCES}

Chacko, E., 2003. Culture and therapy: Complementary strategies for the treatment of type-2 diabetes in an urban setting in Kerala, India. Soc. Sci. Med., 56: 1087-1098

Chehade JM, Mooradian AD. 2000. A Rational Approach to Drug Therapy of Type 2 Diabetes Mellitus, Disease Management. Drugs 60 (1): 95-113.

Chude, M.A., Orisakawe, O.E., Afonne, O.J., Gamanial, K.S., Vongtau, O.H. and, Obi. E., Ghosh, S., and Suryawanshi, S.A., Effect of Vinca rosea extracts in treatment of alloxan diabetic male albino rats, Indian $\mathrm{J}$ Exp Biol ,2001,39: 748-759.

Giovanni, A. and B. Marcelo, 2006. Amerterenoid NF-KB inhibitor and Drimane Sesquiterpenoids from Asfetida. J.Nat. Prod., 69:1101-1104.

Hypoglycemic effect of the aqueous extract of Boerrhavia diffusa leaves, Indian J Pharmacol, 2001, 33:215-216.

Hussain M E M A et al; 2001.Preliminary studies on the hypoglycemic effect of Abroma Augusta in alloxan diabetic rats; Indian Journal of Clinical Biochemistry; Issue: 1; pp:77-80; vol:16.

Omamoto, H., Ucgigata, Y. and Hiroskitckan. STZ and alloxan induces DNA strand breaks and poly (ADP ribose) synthatase in pancreatic islet, Nature, 1981,294:284-286.

Pari L, Uma MJ. 1999. Hypoglycemic effect of Musa sapientum L. in alloxan-induced diabetic rats. Journal of Ethnopharmacology 68: 321-325.

Piedrola G, Novo E, Escober F, Garcia-Robles R. 2001. White blood cell count and insulin resistance in patients with coronary artery disease. Annual Endocrinology (Paris) 62, 7-10.

Raghuramulu N. Madhavan NK, Kalyan Sundaram S. A manual of laboratory techniques. National Institution of Nutrition, Hyderabad. 1983; 205-206.

Shinde $\mathrm{J}$ et al;2008. Alpha-glucosidase inhibitory activity of Syzygium cumini (Linn.) Skeels seed kernel in vitro and in Goto-Kakizaki (GK) rats; Carbohydr Res.; Issue:7; pp:1278-81; vol:343.

Shapiro, K. and W.C. Gong, 2002. Use of herbal products for diabetes by Latinos. J. Am. Pharm. Asso., 42:278279.

Vats RK, Kumar V, Kothari A, Mital A, Uma Ramachandran. 2000. Emerging targets for diabetes. Curr Sci 88: 241-247.

Weidmann P, Boehlen LM, DE Courten M. 1993. Pathogenesis and treatment of hypertension associated with diabetes mellitus. American Heart Journal 125: 1498-1513.

Zimmermann M, 1983. Ethical guidelines for investigations of experimental pain in conscious animals pain, 16 : 109. 